\title{
Technology of mercury removal from exhaust from coal fired boilers
}

\author{
Dariusz Łuszkiewicz ${ }^{1 *}$, Maria Jędrusik ${ }^{1}$, and Arkadiusz Świerczok ${ }^{1}$ \\ ${ }^{1}$ Wrocław University of Science and Technology, Department of Thermal Engineering, 50-370 Wrocław, Poland
}

\begin{abstract}
For the Polish power industry, the basic fuel is hard coal and lignite, which contains significant amounts of mercury. Current emission standards in the European Union (IED directive and in the near future BAT conclusions) create conditions for investment in flue gas cleaning installations for coal-fired power plants. During the combustion of coal, mainly metallic mercury $\left(\mathrm{Hg}^{0}\right)$ is produced, which is difficult to remove from the flue gas in dedusting installations (electrostatic precipitators and fabric filters) and wet flue gas desulphurization plants. In these installations, oxidized mercury $\left(\mathrm{Hg}^{2+}\right)$ and ash bound mercury $(\mathrm{Hg}(\mathrm{p}))$ are removed. In order to reduce the mercury concentration in flue gases, the DEMERTEC technology was created, which is based on the oxidation of metallic mercury to an oxidized form and its removal from flue gas in an existing flue gas de-dusting or de-sulphurization installations. The article presents the results of field tests of the DEMERTEC technology for flue gas from hard coal and lignite. This technology was tested on $\mathrm{a} \sim 400 \mathrm{MW}_{\mathrm{e}}$ unit fed with lignite and on an FGD absorber in which flue gas was purified from two units with a capacity of 195 and $220 \mathrm{MW}_{\mathrm{e}}$ fed with hard coal. In both cases, mercury emissions were reduced below the levels required by the BAT conclusions.
\end{abstract}

\section{Introduction}

The amount of mercury present in the exhaust gases after the boiler is proportional to the mercury content in coal, for Polish deposits, the average content is as follows: hard coal - from 50 to $150 \mathrm{ppb}(1 \mathrm{ppb}=1 \mu \mathrm{g}$ / $\mathrm{kg}$ ); lignite - from 120 to $370 \mathrm{ppb}$ [1]. The mercury contained in the coal in the combustion process at the temperature $>600{ }^{\circ} \mathrm{C}$ [2] passes into the gas phase as elemental mercury $\mathrm{Hg}^{0}$. Elemental mercury vapours are not very reactive and are insoluble in water [3]. Lowering the flue gas temperature in heat exchangers causes that part of $\mathrm{Hg}^{0}$ is oxidized to the $\mathrm{Hg}^{2+}$ form (called ionic mercury or oxidized mercury) [3]. $\mathrm{Hg}^{2+}$ is the name of all water-soluble mercury compounds, the main of such compounds in the process of combustion of hard coal is $\mathrm{HgCl}_{2}$ (there is also $\mathrm{HgBr}_{2}, \mathrm{HgI}_{2}, \mathrm{HgF}_{2}$, $\mathrm{HgO}, \mathrm{HgSO}_{4}$ and $\mathrm{Hg}\left(\mathrm{NO}_{3}\right)_{2}$ ) [4]. In the case of lignite combustion, due to the lack of halides $\left(\mathrm{Cl}_{2}, \mathrm{Br}_{2}\right.$ and $\left.\mathrm{I}_{2}\right)$, the share of $\mathrm{Hg}^{2+}$ in the exhaust gases behind the boiler is small. Oxidized mercury present in the flue gas can be adsorbed on the fly ash surface, creating the so-called $\mathrm{Hg}(\mathrm{p})$ - oxidized mercury bound to fly ash [5]. Due to the extreme harmfulness of mercury, various countries have adopted regulations limiting its emission into the atmosphere. For example, in the European Union, BAT -conclusions were established. The permissible mercury concentrations in the flue gas resulting from the BAT conclusions [6] refer to the total mercury $\mathrm{Hg}^{\mathrm{T}}$ defined as: $\mathrm{Hg}^{\mathrm{T}}=\mathrm{Hg}^{0}+\mathrm{Hg}^{2+}+\mathrm{Hg}(\mathrm{p})$.

The effectiveness of mercury removal in existing flue gas cleaning devices depends on the form of mercury present in the flue gas, where; in dust collectors, oxidized mercury associated with dust $\mathrm{Hg}(\mathrm{p})$ is removed with high efficiency [3], in flue gas desulphurization (FGD) installations oxidized mercury $\mathrm{Hg}^{2+}$ is removed [7]. The effectiveness of metallic mercury removal in these devices is low. For this reason, the conversion of $\mathrm{Hg}^{0}$ to $\mathrm{Hg}^{2+}$ in the boiler flue gas is extremely important. Oxidized mercury can be removed from the flue gas in the FGD absorber with an efficiency of up to $90 \%$ [2]. The effectiveness of mercury removal from flue gas in the FGD absorber is limited by the phenomenon of its re-emission (the $\mathrm{Hg}^{0}$ concentration downstream of the absorber is higher than the $\mathrm{Hg}^{0}$ concentration in the flue gas flowing into device) [8]. This phenomenon consists in the chemical reduction of $\mathrm{Hg}^{2+}$ absorbed in $\mathrm{CaCO}_{3}$ slurry to elemental mercury emitted to the atmosphere [9]. The course of this process is influenced by many factors, including: sulphite concentration in the slurry, absorber operating parameters $(\mathrm{pH}, \mathrm{ORP}$, slurry temperature, air stream fed to the absorber), organic acid concentration and $\mathrm{Hg}^{2+}$ concentration in the flue gas upstream the absorber [8 $10]$.

\section{Basis of the technology}

As a result of cooperation between Wrocław University of Science and Technology and RAFAKO S.A. The DEMERTEC technology has been developed, which is dedicated to both existing and new unit fired by hard coal and lignite. Two additives are used in this

\footnotetext{
* Corresponding author: dariusz.luszkiewicz@pwr.edu.pl
} 
technology: oxidizing and to limit the phenomenon of $\mathrm{Hg}$ re-emission from the FGD absorber. The technology is covered by patent no. PL $231036 \mathrm{~B} 1$ and patent application $\mathrm{P}$ 420709. The variants of DEMERTEC technology are shown at Fig. 1.

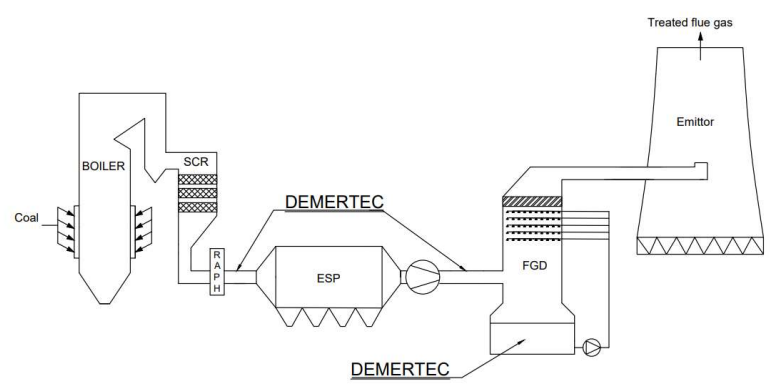

Fig. 1. Variants of DEMERTEC technology.

The DEMERTEC technology consists in injection an oxidizing additive (its composition is dependent on composition of flue gas) into the flue gas that enables the oxidation of $\mathrm{Hg}^{0}$ to $\mathrm{Hg}^{2+}$. Depending on the injection point of the additive, oxidized mercury is removed in the dust collector (the role of the $\mathrm{Hg}^{2+}$ adsorbent is played by fly ash) or in the wet FGD installation. The process of $\mathrm{Hg}^{2+}$ adsorption on dust particles (efficiency increases with the carbon content in fly ash), reduces mercury emissions by forming $\mathrm{Hg}(\mathrm{p})$. In the case of the absorption of $\mathrm{Hg}^{2+}$ in the $\mathrm{CaCO}_{3}$ slurry, it is necessary to limit the phenomenon of re-emission. This phenomenon is limited by the additive which, when is added to the slurry in the absorber, forms mercury sulphide $(\mathrm{HgS})$, which is a stable compound (up to the temperature of $265^{\circ} \mathrm{C}$ [11]) and insoluble in water [12]. At the same time other metals dissolved in the suspension are also removed $(\mathrm{Zn}, \mathrm{Cd}, \mathrm{Pb}, \mathrm{Cr}, \mathrm{Cu}, \mathrm{Ni}$, $\mathrm{Mn}$ and $\mathrm{Fe}$ ), which reduces their concentration in the wastewater from the FGD installation.

\section{Full scale tests}

Tests of the DEMERTEC technology were carried out on objects fed with hard coal and lignite. During the tests on the hard coal-fired facility, fuel with an average calorific value of $21.1 \mathrm{MJ} / \mathrm{kg}$, mercury content of 0.066 $\mathrm{mg} / \mathrm{kg}$ and halides (sum of $\mathrm{Cl}, \mathrm{F}$ and $\mathrm{Br}$ ) of $0.148 \%$ in the working state of the fuel was burned. For the tests for the lignite-fired unit, fuel with an average calorific value of $10.1 \mathrm{MJ} / \mathrm{kg}$, mercury content of $0.335 \mathrm{mg} / \mathrm{kg}$ and a trace content of halides (sum of $\mathrm{Cl}, \mathrm{F}$ and $\mathrm{Br}$ ) $<0.01 \%$ in the working state of fuel was burned.

The location of the additive injection point during field tests is shown at Fig. 2. As a part of the research, continuous measurements of mercury concentration in the flue gas were carried out (using two Gasmet mercury continuous emission monitoring systems (CEMS)) in the measurement cross-sections located in front of the injection site (A) and in the chimney (C) . Additionally, mercury speciation was measured using the manual method (Ontario-Hydro) in the chimney (C), upstream the FGD absorber (B) and upstream the injection site of the oxidizing additive (A). Based on the continuous measurements of mercury concentration in the flue gas before the absorber and in the chimney, the effectiveness of mercury removal from flue gas in the FGD absorber was calculated using the formula:

$$
\eta_{H g}=\left(1-\left(H^{T} \mathrm{C} / \mathrm{Hg}^{T} \mathrm{~A}\right)\right) \cdot 100 \%
$$

where:

$\mathrm{Hg}^{\mathrm{T}} \mathrm{C}$ - average concentration of total mercury in the flue gas in the stack (C), $\mu \mathrm{g} / \mathrm{m}^{3} \mathrm{usR}_{\text {; }}$

$\mathrm{Hg}^{\mathrm{T}} \mathrm{A}$ - average concentration of total mercury in the exhaust gas before the absorber (A), $\mu \mathrm{g} / \mathrm{m}^{3} \mathrm{UsR}$.

Due to the fact that the measurements of mercury concentration were performed downstream of a highefficiency dust collector (electrostatic precipitator), the concentration of $\mathrm{Hg}(\mathrm{p})$ in the flue gas was negligible and only $\mathrm{Hg}^{0}$ and $\mathrm{Hg}^{2+}$ were taken into account when calculating the $\mathrm{Hg}^{\mathrm{T}}$ concentration in the flue gas.

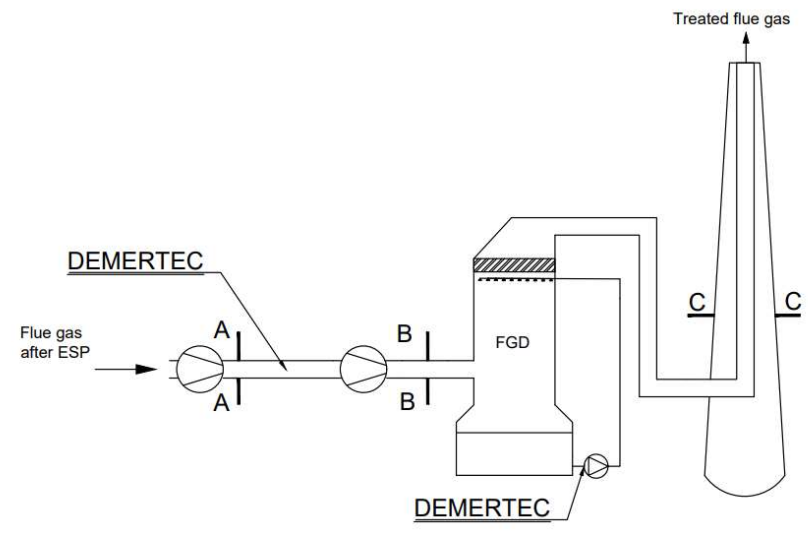

Fig. 2. Measurements site during the full scale tests

\subsection{Lignite fired boiler}

The tests were carried out with the use of flue gas from a lignite-fired pulverized boiler $\left(400 \mathrm{MW}_{\mathrm{e}}\right)$ equipped with a selective non-catalytic NOx reduction installation, electrostatic precipitator and wet flue gas desulphurization installation. The FGD absorber is equipped with 4 spraying levels and a system for addition of adipic acid to the $\mathrm{CaCO}_{3}$ slurry in order to increase the efficiency of desulphurization. The research installation for the injection of oxidizing additive (sodium chlorite at a concentration of $25 \%$ ) was built between the exhaust fan and the fan supporting the FGD installation. The choice of the injection point of the additive before the booster fan guaranteed a very good mixing of the oxidizing additive with the exhaust gas.

Measurements results of the concentration of individual mercury forms present in the exhaust gas with and without sodium chlorite injection $\left(1.8 \mathrm{~m}^{3} / \mathrm{h}\right)$ are shown at Fig. 3. When the oxidant was not supplied, the share of metallic mercury (in sections A and B) was much higher (approx. 90\% $\mathrm{Hg}^{\mathrm{T}}$ ) than oxidized (up to $10 \% \mathrm{Hg}^{\mathrm{T}}$ ) and the efficiency of total mercury removal in the FGD absorber reached 40\%. During the administration of the oxidation additive to the exhaust gas, the share of oxidized mercury in the exhaust gas increased (up to $60 \% \mathrm{Hg}^{\mathrm{T}}$ ) in the measuring crosssection downstream of the injection point (B), which translated into a higher efficiency of total mercury removal in FGD absorber $(76 \%)$. The results of the efficiency of $\mathrm{Hg}^{\mathrm{T}}$ removal from the flue gas as a function of the $\mathrm{NaClO}_{2}$ stream injected into the flue gas are 
presented in Fig. 4. The efficiency of mercury removal in the FGD absorber increased with the amount of oxidant injected into the flue gas, which was related to the increased concentration of $\mathrm{Hg}^{2}+$ in the flue gas before the absorber. During the tests, up to $89 \%$ mercury removal efficiency was achieved in the FGD absorber when injecting the oxidant into the flue gas.

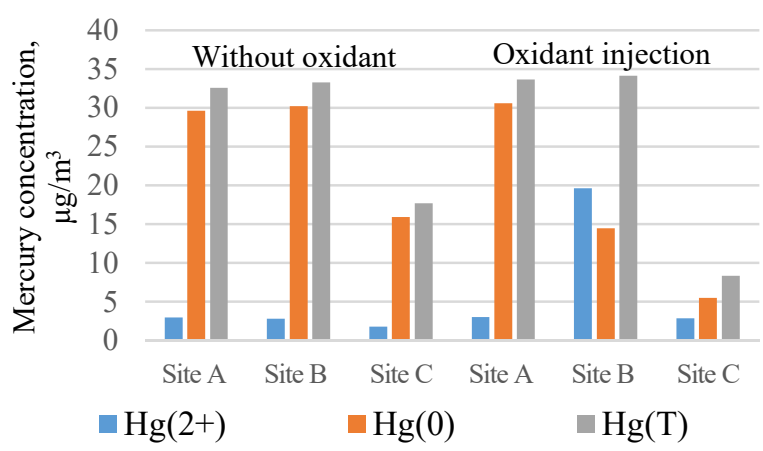

Fig. 3. Measurements results of individual mercury form in exhaust gas during the test of oxidizing additive $(1,8 \mathrm{~m} 3 / \mathrm{h})$. Concentration under so called reference conditions: dry gas at a temperature of $273.15 \mathrm{~K}$, and a pressure of $101,3 \mathrm{kPa}$, calculated for oxygen content in the flue gas $\mathrm{O} 2=6$ vol- $\%$.

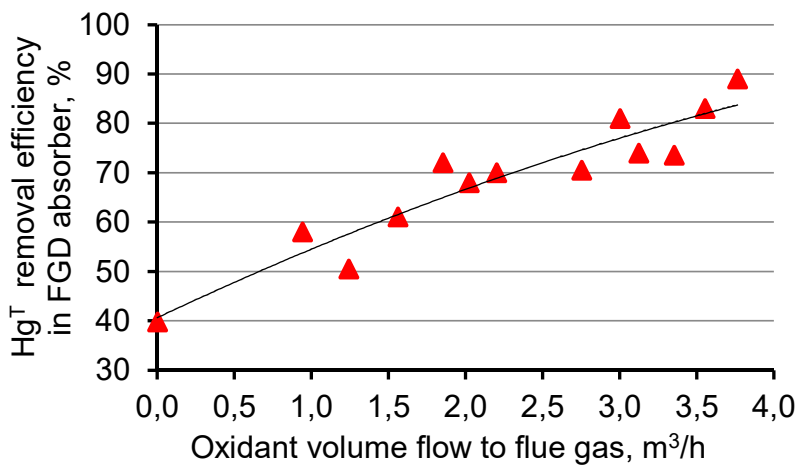

Fig. 4. Total mercury removal efficiency in FGD absorber in function of amount of oxidizing additive feed to flue gas.

\subsubsection{Re-emission removal}

Due to the fact that the increase in the amount of oxidized mercury in the exhaust gas before the FGD absorber contributes to the intensification of the phenomenon of mercury re-emission [8], tests were carried out on the same unit with the addition of a sulphide-based agent to limit re-emission. The additive was fed at the pump suction for the highest spraying level and directly to the tank under the absorber. Fig. 5 shows the results of adding the additive (sulphide mixture) in a total dose of $4 \mathrm{~m}^{3}$, first directly to the tank under the absorber $\left(2 \mathrm{~m}^{3}\right)$, and then in the amount of 250 $\mathrm{dm}^{3} / \mathrm{h}$ to the highest level of spraying system of the FGD absorber. In this way, the concentration of total mercury in the flue gas was reduced below the level required in the BAT conclusions for a period of 8 hours.

The addition of an additive to prevent re-emission to the $\mathrm{CaCO}_{3}$ slurry in the absorber caused the precipitation of metals from the suspension through the formation of sparingly soluble sulphides. Table 1 summarizes the results of measurements of the metals concentration in the filtrate of the $\mathrm{CaCO}_{3}$ slurry taken from the absorber before and after the addition of the additive. A sample of the $\mathrm{CaCO}_{3}$ slurry was taken from the absorber, then filtered with a hard filter and the clear filtrate was analysed for metals. The concentration of mercury, zinc, lead, cadmium, chromium, copper, nickel, iron and manganese in the liquid was determined. After its administration, the concentration of metals in the liquid dropped significantly, with mercury being the most effective $(93 \%)$.

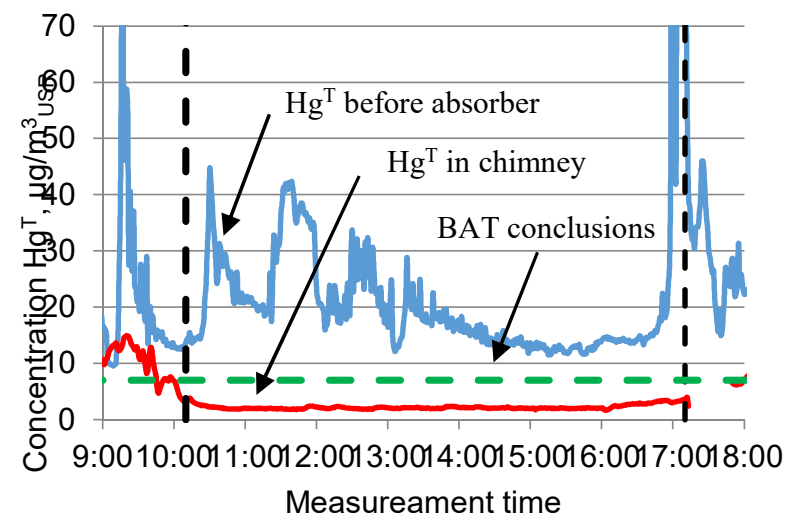

Fig. 5. Concentraion of total mercury on chimney and before FGD absorber during the test with additive for prevent reemision.

Table 1. Concentration of metals in a samples of $\mathrm{CaCO}_{3}$ slurry collected during the tests

\begin{tabular}{|c|c|c|c|}
\hline \multirow{2}{*}{ Metal } & \multicolumn{3}{|c|}{ Value } \\
\cline { 2 - 4 } & $\begin{array}{c}\text { Before } \\
\text { additive }\end{array}$ & $\begin{array}{c}\text { After } \\
\text { additive }\end{array}$ & $\begin{array}{c}\text { Precipitation } \\
\text { effectiveness }\end{array}$ \\
\cline { 2 - 4 } & $\mathrm{mg} / \mathrm{dm}^{3}$ & $\mathrm{mg} / \mathrm{dm}^{3}$ & $\%$ \\
\hline $\mathrm{Hg}$ & 0,029 & 0,002 & 93,1 \\
\hline $\mathrm{Zn}$ & 0,852 & 0,264 & 69,0 \\
\hline $\mathrm{Pb}$ & $<0,023$ & $<0,023$ & - \\
\hline $\mathrm{Cd}$ & 0,078 & $<0,023$ & 70,5 \\
\hline $\mathrm{Cr}$ & $<0,030$ & $<0,030$ & - \\
\hline $\mathrm{Cu}$ & 0,047 & $<0,026$ & 44,6 \\
\hline $\mathrm{Ni}$ & 0,559 & 0,466 & 16,6 \\
\hline $\mathrm{Fe}$ & 0,429 & $<0,305$ & 28,9 \\
\hline $\mathrm{Mn}$ & 153 & 47,7 & 68,8 \\
\hline
\end{tabular}

To sum up, due to the low content of halides in lignite in the flue gas, elemental mercury is present mainly, which means that the effectiveness of $\mathrm{Hg}^{\mathrm{T}}$ emission reduction in the existing flue gas treatment installations is not sufficient to achieve the emission levels in line with the BAT conclusions. The efficiency of total mercury removal in FGD absorber can be increased by the oxidation of $\mathrm{Hg}^{0}$ to $\mathrm{Hg}^{2+}$ with an oxidizing additive in the flue gas. In this case it is extremely important to reduce the re-emission phenomenon by using a specially selected additive that causes mercury to precipitate in a stable form of $\mathrm{HgS}$. As shown by the results of field tests, the application of the DEMERTEC technology on a lignite-fired unit allows to achieve mercury emission levels in line with the BAT conclusions. 


\subsection{Hard coal fired boiler}

The tests on hard coal were carried out in the FGD absorber, in which the flue gases from two 195 and 220 MWe power units were cleaned. The boilers are equipped with SNCR installations. During the tests, both boilers operated at maximum capacity. Before starting the research, measurements were made using the Ontario-Hydro method, which revealed that the absorber is experiencing the phenomenon of metallic mercury re-emission. The results of these measurements are shown at Fig. 6.

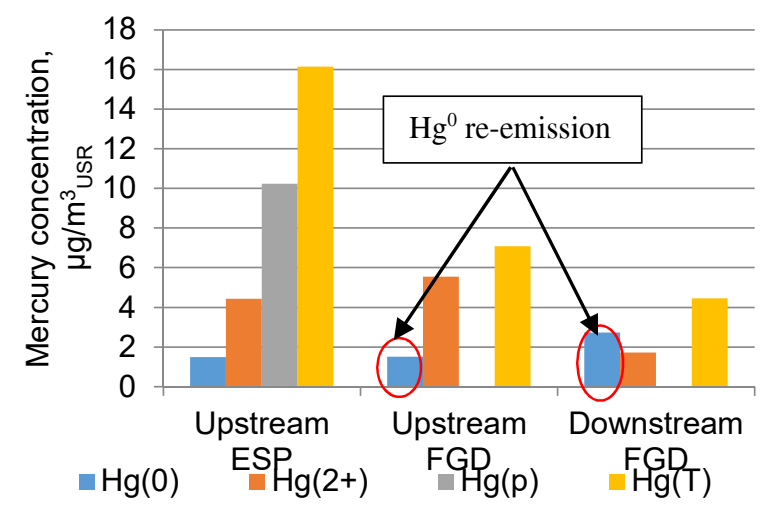

Fig. 6. Measurements results of individual mercury form in exhaust gas during the test

Total mercury removal efficiency in the exhaust gas treatment installation (electrostatic precipitator and FGD absorber) was $72.4 \%$. The mercury associated with the ash was virtually completely removed in the electrostatic precipitator. The flue gas behind the boiler contained a small amount of metallic mercury $(1.73 \mu \mathrm{g}$ $/ \mathrm{m}^{3} \mathrm{USR}$ ), which results from the high content of halides in the fuel. The concentration of metallic mercury in the exhaust gas upstream the absorber was lower than downstream the absorber, which means that the mercury re-emission phenomenon occurred in the absorber. The total mercury removal efficiency in the ESP was $56.2 \%$, and in the FGD absorber - 36.9\%. Due to the fact that the proportion of oxidized mercury upstream of the FGD absorber is significant, no oxidant was introduced into the flue gas and the tests were carried out with an additive to reduce re-emissions.

The additive in the amount of $2 \mathrm{~m}^{3}$ was fed once directly to the tank under the absorber. Fig. 7 shows the results of measurements of mercury concentration in the exhaust gas up- and downstream the FGD absorber during the dosing of the additive. Measurements were made with two continuous emission monitoring systems (upstream FGD absorber (B) and in chimney (C)).

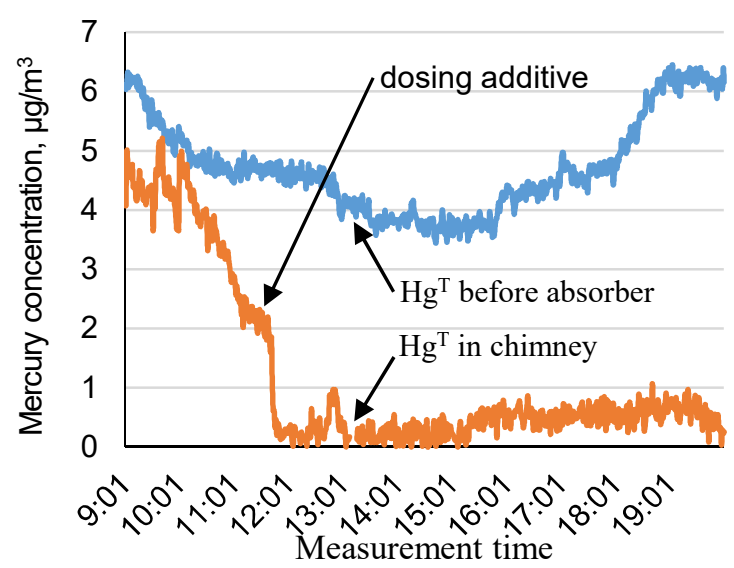

Fig. 7. Results of measurement of mercury (CEMS) before FGD absorber and in chimney during additive dosing. Concentration under so called reference conditions: dry gas at a temperature of $273.15 \mathrm{~K}$, and a pressure of $101,3 \mathrm{kPa}$, calculated for oxygen content in the flue gas $\mathrm{O}_{2}=6$ vol- $\%$.

The concentration of total mercury in the exhaust gas at the absorber outlet prior to the administration of additive to prevent re-emission was $4.3 \mu \mathrm{g} / \mathrm{m}^{3}$. After the addition of the additive, the average concentration of total mercury in the exhaust gas dropped to the level of $0.45 \mu \mathrm{g} / \mathrm{m}^{3}$. The efficiency of mercury removal from flue gas in the FGD absorber was $25.5 \%$ without the addition of additive and increased to $90.5 \%$ after the addition of the additive. As for the measurements on brown coal, samples of the $\mathrm{CaCO}_{3}$ slurry were taken, filtered and the concentration of metals in the liquid was determined, the results are summarized in Table 2.

Table 2. Concentration of metals in a samples of $\mathrm{CaCO}_{3}$ slurry collected during the tests

\begin{tabular}{|c|c|c|c|c|}
\hline \multirow{3}{*}{ Metal } & \multirow{3}{*}{ Unit } & \multicolumn{3}{|c|}{ Value } \\
\hline & & $\begin{array}{c}\text { Before } \\
\text { additive }\end{array}$ & $\begin{array}{c}\text { After } \\
\text { additive }\end{array}$ & $\begin{array}{l}\text { Precipitation } \\
\text { effectiveness }\end{array}$ \\
\hline & & $\mathrm{mg} / \mathrm{dm}^{3}$ & $\mathrm{mg} / \mathrm{dm}^{3}$ & $\%$ \\
\hline $\mathrm{Hg}$ & \multirow{6}{*}{$\mu \mathrm{g} / \mathrm{dm}^{3}$} & 9,35 & 1,60 & 82,9 \\
\hline $\mathrm{Pb}$ & & 80,5 & 76,3 & 5,21 \\
\hline $\mathrm{Cd}$ & & 346 & 250 & 27,7 \\
\hline $\mathrm{Cr}$ & & 4,51 & 2,29 & 49,2 \\
\hline $\mathrm{Cu}$ & & 33,0 & 31,0 & 6,06 \\
\hline $\mathrm{Ni}$ & & 175 & 170 & 2,85 \\
\hline $\mathrm{Zn}$ & \multirow{3}{*}{$\mathrm{mg} / \mathrm{dm}^{3}$} & 23,4 & 22,7 & 3,00 \\
\hline $\mathrm{Fe}$ & & 1,77 & 0,90 & 49,2 \\
\hline $\mathrm{Mn}$ & & 5,34 & 4,78 & 10,5 \\
\hline
\end{tabular}

The addition of an additive to the $\mathrm{CaCO}_{3}$ slurry caused a reduction in the concentration of all measured metals in the liquid from the absorber, and the highest precipitation efficiency was obtained for mercury. The removal of mercury from the slurry clearly improved the effectiveness of $\mathrm{Hg}^{2+}$ removal from the flue gas.

In summary, due to the content of halides in coal, there is a significant amount of $\mathrm{Hg}^{2+}$ in hard coal flue gas, which can be effectively removed in FGD absorber, provided that the re-emission phenomenon is controlled. The use of an appropriate additive allows to limit this phenomenon, which is illustrated by the results of object-oriented tests. 


\section{Summary}

In summary, the DEMERTEC technology is characterized by:

- Low investment outlays - resulting from the use of the existing flue gas dedusting and desulphurization installations to remove $\mathrm{Hg}^{\mathrm{T}}$ from flue gases;

- Flexibility - the configuration of the installation is selected on the basis of the required degree of flue gas cleaning, taking into account the specific conditions on the site (speciation of mercury in the flue gas and existing atmosphere protection installations);

- Regulability - changes in the amount of oxidizing additive injected into the flue gas cause immediate changes in the concentration of pollutants in the chimney;

- Safety - oxidized mercury removed from the flue gas in the FGD absorber with the addition of an additive limiting re-emission is retained in a durable and safe form of $\mathrm{HgS}$, which reduces its negative impact on the environment;

- Efficiency - the efficiency of mercury removal from flue gas by means of the DEMERTEC technology reaches $90 \%$, which enables compliance with the provisions of the BAT conclusions.

The above-mentioned features of the DEMERTEC technology make it a solution that allows to achieve total mercury emission levels in accordance with the requirements of BAT conclusions. This technology is particularly useful for existing coal units, because the existing atmosphere protection devices (electrostatic precipitators, FGD absorbers) are used for flue gas cleaning, which was confirmed by tests under real conditions.

\section{References}

1. Lorenz U., Grudziński Z., Zawartość rtęci jako potencjalny czynnik ograniczający wartość użytkową węgla kamiennego i brunatnego, Górnictwo i geoinżynieria, 31 3/1, 335-349, 2007.

2. Niksa S., Fujiwara N., The impact of wet flue gas desulfurization scrubbing on mercury emissions from coal-fired power stations, J. Air Waste Manage. Assoc., 55, 970-977, 2005.

3. Zhang L., Wang S., Wu Q., Wang F., Lin C., Zhang L., Hui M., Yang M., Su H., Hao J., Mercury transformation and speciation in flue gases from anthropogenic emission sources: a critical review, Atmos. Chem. Phys., 16, $2417-$ 2433, 2016.

4. Senior C. L., Sarofim A. F., Zeng T., Helble J. J., Mamani-Paco R., Gas-phase transformations of mercury in coal-fired power plants, Fuel Process. Technol., 63, 197-213, 2000.
5. Jędrusik M., Świerczok A., Krzyżyńska R., Usuwanie rtęci w elektrofiltrach. Przemysł Chemiczny, 93(11), 1885-1888, 2014.

6. DECYZJA WYKONAWCZA KOMISJI (UE) 2017/1442 z dnia 31 lipca 2017 r. ustanawiająca konkluzje dotyczące najlepszych dostępnych technik (BAT) w odniesieniu do dużych obiektów energetycznego spalania zgodnie $\mathrm{z}$ dyrektywą Parlamentu Europejskiego i Rady 2010/75/UE (C(2017) 5225)

7. Krzyżyńska R., Hutson N. D., Effect of solution $\mathrm{pH}$ on $\mathrm{SO}_{2}, \mathrm{NO}_{\mathrm{x}}$ and $\mathrm{Hg}$ removal from simulated flue gas in a oxidant-enhanced wet scrubber, J. Air Waste Manage. Assoc., 62(2), 212-220, 2012.

8. Jędrusik M., Gostomczyk M. A., Świerczok A., Łuszkiewicz D., Kobylańska M., Mercury reemission from adipic acid enhanced FGD absorber - full scale investigations on $~ 400$ MWe boiler (lignite) with oxidant injection to flue gas, Fuel, 238, 507-531, 2019

9. Ochoa-Gonzales R., Diaz-Somoano M., MartinezTarazona MR., Control of $\mathrm{Hg}^{0}$ re-emission from gypsum slurries by means of additives in typical wet scrubber conditions, Fuel, 105, 112-118, 2013.

10. Heidel B., Hilber M., Scheffknecht G., Impact of additives for enhanced sulfur dioxide removal on re-emissions of mercury in wet flue gas desulfurization, App. Energy, 114, 485-491, 2014.

11. Leckey, J. H., and Nulf, L. E. Thermal decomposition of mercuric sulfide. United States: N. p., 1994. Web. doi:10.2172/41313.

12. Wichliński M., Kobyłecki R., Bis Z., Badania zawartości rtęci w ptytach gipsowo-kartonowych $i$ $w$ gipsach, JCEEA, t. XXXIII, z. 63 (4/16), 565572, 2016.A. Mecke, I. Lee, J.R. Baker jr., M.M. Banaszak Holl, B.G. Orr, Eur. Phys. J. E 14, 7 (2004) 